\title{
MAGIC ROUND: TEACHING MEDIA FOR COMPILING NEGATIVE SENTENCES
}

\author{
Tri Agustini Solihati \\ English Education Department, Faculty of Education and Teacher Training, \\ Universitas Perjuangan Tasikmalaya, Indonesia \\ E-mail: try_leocps@yahoo.co.id
}

Gea Aristi

Informatics Engineering Department, Faculty of Engineering, Universitas Perjuangan Tasikmalaya, Indonesia

E-mail: geaaristi@gmail.com

\begin{abstract}
APA Citation: Solihati, T. A., \& Aristi, G. (2018). Magic round: Teaching media for compiling negative sentences. Indonesian EFL Journal, 5(1), 95-106. doi: 10.25134/ieflj.v5i1.1628.
\end{abstract}

Received: 22-09-2018

Accepted: 28-11-2018

Published: 01-01-2019

\begin{abstract}
Learning English is much harder for Indonesian students because of various aspects. Yet, the obstacles are able to overcome with any methods, strategies or media to achieve the goals of the teaching and learning process (Manan, 2017). This research focuses on developing teaching media, named Magic Round for teaching negative sentences. It was made to facilitate students in compiling grammatically correct sentences. This research was carried out by applying Research and Development $(\mathrm{R} \& \mathrm{D})$ which consists of several steps, including; preliminary studies, research planning, product design, product validation, product trial, and producing final product. The trial result in limited scale gained $81.67 \%$ from technology expert and $86.67 \%$ from material expert. Besides, the assessment of its usefulness, feasibility, and students' responses toward the media reached $86.38 \%, 88.64 \%$, and $87.18 \%$, respectively. It means that Magic Round is valid and can be used without revision. In conclusion, Magic Round is appropriate to use in teaching English negative sentences.
\end{abstract}

Keywords: magic round; negative sentences; research and development; teaching media; tenses.

\section{INTRODUCTION}

Compiling various types of sentence including the use of correct grammar becomes an essential part in communication. The way someone expresses the sentence will determine the intended message or information delivered. It happens in both oral and written communication. The most influential aspects to writing are vocabulary and grammar (Soviyah \& Etikaningsih, 2018). Therefore, grammar needs to be not only memorized but also comprehended by students (Haryudin, \& Argawati, 2018).

Moreover, students also face the obstacles on language gap between English and Bahasa Indonesia. The gap then leads to students' mistakes in writing. They often mix the grammar blindly and translate the words or phrases directly. In fact, English and Bahasa Indonesia are different in term of structural, grammatical, terms, and styles (Soviyah \& Etikaningsih, 2018). Yet, the obstacle in English teaching and learning can be overcome by using an appropriate method, strategy, or media (Manan, 2017). One of the teaching media that can be used is Magic Round. As confirmed by Solihati (2017), Magic Round is an appropriate teaching media that can be used in understanding affirmative sentences including the right tenses.

Some of the strengths of using Magic Round for teaching English sentences are; 1) it provides joyful learning, 2) it gives the opportunity to autonomous learning, 3 ) it is completed by verbs' translation in Bahasa Indonesia, and 4) it is quiet easy to play and learn along it. These strengths are in line 
with the characteristics of teaching media which are; 1) able to clarify the message, 2) able to overcome the limitation of time, space, and energy, 3) having more direction between student and teacher, 4) enabling students to learn independently, and 5) able to fulfill five components in learning process; teacher, material, media, student, and learning goals (Daryanto, 2016).

As it is implied in its name, Magic Round Negative focuses on negative sentences. It is about how to learn simple negative sentences. Here, the type of sentences will be limited to verbal sentence. Thus, the predicate in the sentences should be in the form of verb and the verbs themselves are irregular verbs. However, mastering the verbs form is very challenging for most students. They usually tried to predict and guess as they want. As result, they are confused to differ between regular and irregular verbs. They sometimes consider regular verbs as irregular or vice versa.

Negative sentences were sentences that have "no" or "not". That is what almost all students know. So, the common mistakes appear while making sentences are putting "no" or "not" wherever they want without applying the appropriate formula. Here is the pattern that students should know to arrange good sentences with full consideration on tenses.

Table 1. Pattern and tenses for negative sentence

\begin{tabular}{ccccc}
\hline & Present & Past & Future & Past Future \\
\hline Simple & S+Do/does not+V1 & S+Did not+V2 & S+will+not+V1 & S+would+not+V1 \\
Continuou & S+am/are/is+not+Ving & S+was/were+not+v.ing & S+will+not+be+ & S+would+not+be \\
S & & & Ving & + V.ing \\
Perfect & S+have/has+not+V3 & S+had not+V3 & S+will+not+hav & S+would+not+hav \\
& & & e+V3 & e+V3 \\
Perfect & S+have/has+not+been & S+had+not+been+Ving & $\begin{array}{c}\text { S+will+not+hav } \\
\text { e+been+Ving }\end{array}$ & $\begin{array}{c}\text { S+would+not+hav } \\
\text { e+been+V.ing }\end{array}$ \\
$\begin{array}{c}\text { Continuou } \\
\text { S }\end{array}$ & +Ving & & & \\
\hline
\end{tabular}

After using Magic Round Negative, students are expected to be able to comprehend the 16 (sixteen) tenses, including simple present tenses, simple past tense, simple future tense, simple past future tenses, present continuous tense, past continuous tense, future continuous tenses, past future continuous tense, present perfect tense, past perfect tense, future perfect tense, past future perfect tense, present perfect continuous tense, past perfect continuous tense, future perfect continuous tense, and past future perfect continuous tense. Yet, the first thing that students should master is their names which can be done by memorizing by only 4 (four) cores of time, which are present, past, future, and past future. After that, they can easily combine them to the complete names by mixing "Secoperpeci".
This is an abbreviation of Se (Simple), Co (continuous), Per (Perfect), and Peci (Perfcet Continuous). Secoperpeci is very familiar term for Indonesian.

\section{METHOD}

This study was conducted at State Islamic Senior High School 2 (Madrasah Aliyah Negeri 2) Tasikmalaya, exactly in XI-IIK 1 class which consists of 38 students. This study applied Research and Development (R\&D) that consists of 6 (six) steps, namely preliminary study, planning, product design, product validation, product trial, and final product. The modification of the model is presented in Table 2 and the description of the instrument used to collect data is shown in Table 3. 
Table 2. Research model

\begin{tabular}{|c|c|}
\hline Step 1: Preliminary Study & 1. Finding references \\
\hline & 2. Field Observation \\
\hline & 3. Problem Identification \\
\hline & 4. Needs Identification \\
\hline Step 2: Planning & 1. Identifying general goal in learning process \\
\hline & 2. Analyzing learning process to develop the media \\
\hline & 3. Formulating learning objective \\
\hline & 4. Developing learning strategy \\
\hline & 5. Developing or selecting the appropriate material \\
\hline & 6. Developing test \\
\hline & 7. Developing learning outcome instrument \\
\hline & 8. Developing instrument for product validation \\
\hline Step 3: Product Design & 1. Product design; Magic Round Negative \\
\hline & 2. Guidance book \\
\hline & 3. Lesson plan \\
\hline Step 4: Product & 1. Technology expert \\
\hline Validation & 2. Material expert \\
\hline & 3. Teacher \\
\hline & 4. Observer \\
\hline & 5. Students/Users \\
\hline Step 5: Product Trial & 1. Individual scale \\
\hline & 2. Product revision part 1 \\
\hline & 3. Small scale \\
\hline & 4. Product revision part 2 \\
\hline & 5. Limited scale \\
\hline & 6. Product revision part 3 \\
\hline Step 6: Final Product & 1. Magic Round Negative \\
\hline & 2. Guidance book \\
\hline & 3. Lesson plan \\
\hline
\end{tabular}

Table 3. Research instrument

\begin{tabular}{l} 
Assessed Aspects \\
\hline $\begin{array}{l}\text { The accuracy of teaching media } \\
\text { (Magic Round) }\end{array}$ \\
The usefulness and the feasibility \\
of teaching media (Magic Round)
\end{tabular}

The effectiveness of teaching media (Magic Round)

\begin{tabular}{|c|c|c|}
\hline Instruments & Observed Data & Respondent \\
\hline $\begin{array}{c}\text { Validation } \\
\text { questionnaire of } \\
\text { teaching media (Magic } \\
\text { Round) }\end{array}$ & $\begin{array}{l}\text { Validation questionnaire } \\
\text { of teaching media } \\
\text { (Magic Round) and } \\
\text { teacher's guide book }\end{array}$ & $\begin{array}{c}\text { Technology } \\
\text { expert and } \\
\text { material expert }\end{array}$ \\
\hline $\begin{array}{l}\text { Observation sheet of } \\
\text { teaching media } \\
\text { usefulness (Magic } \\
\text { Round) }\end{array}$ & $\begin{array}{l}\text { Learning activity using } \\
\text { teaching media (Magic } \\
\text { Round) and teacher's } \\
\text { guide book }\end{array}$ & Observer \\
\hline $\begin{array}{l}\text { Teacher's response } \\
\text { questionnaire }\end{array}$ & $\begin{array}{l}\text { Response and teacher's } \\
\text { opinion toward } \\
\text { feasibility of teaching } \\
\text { media (Magic Round) }\end{array}$ & Teacher \\
\hline $\begin{array}{l}\text { Students' responses in } \\
\text { using teaching media } \\
\text { (Magic Round) }\end{array}$ & $\begin{array}{l}\text { Students' responses } \\
\text { after studying with } \\
\text { teaching media } \\
\text { (Magic Round) }\end{array}$ & Students \\
\hline $\begin{array}{l}\text { Test of students' } \\
\text { achievement }\end{array}$ & The result of the test & Students \\
\hline
\end{tabular}

For analysing the accuracy of teaching media, the questionnaire consists of 15 (fifteen) indicators, 33 (thirty three) indicators to examine the usefulness of magic round negative, and 15 (fifteen) indicators in students' questionnaire. On the other hand, the test consists of 35 (thirty five) questions in both pre-test and post-test. Each questionnaire consists of four scale 1 to 4 in which the numbers indicated the level of agreement; less agree, agree enough, agree, and strongly agree. The analysis results of 
Tri Agustini Solihati \& Gea Aristi

Magic round: Teaching media for compiling negative sentences

the instruments were then interpreted by (2012) as shown in Table 4. using the criteria adopted from Widoyoko

Table 4. Data interpretation

\begin{tabular}{cll}
\hline No. & Percentage & Description \\
\hline 1. & $86 \%-100 \%$ & Quiet valid and practical, can be used without revision \\
2. & $71 \%-85 \%$ & Valid and practical enough, can be used with a little revision \\
3. & $56 \%-70 \%$ & Less valid and practical, need much revision \\
4. & $41 \%-55 \%$ & Not valid and practical, cannot be used \\
5. & $26 \%-40 \%$ & Not valid at all, cannot be used \\
\hline
\end{tabular}

\section{RESULTS AND DISCUSSION}

Magic Round Negative had been developed by using Corel Draw Application. It was shaped round and being dominated by red colour. Its diameter was $24 \mathrm{~cm}$. It had 4 (four) layers with different content for each layer. The first layer had sentences pattern for each kind of tenses. On the right side, there was sentences pattern for simple type and directed to green box for simple form. On the left, there was sentences pattern for perfect type and directed to aquamarine box for participle form. Then, in the middle side, there was sentences pattern for continuous and perfect continuous and also directed to yellow box for -ing form. The first layer was also decorated by several balloons that put the abbreviations of "not", such as hadn't, hasn't, weren't, don't, doesn't, aren't, wouldn't, didn't, haven't, won't, isn't, wasn't, and wouldn't.

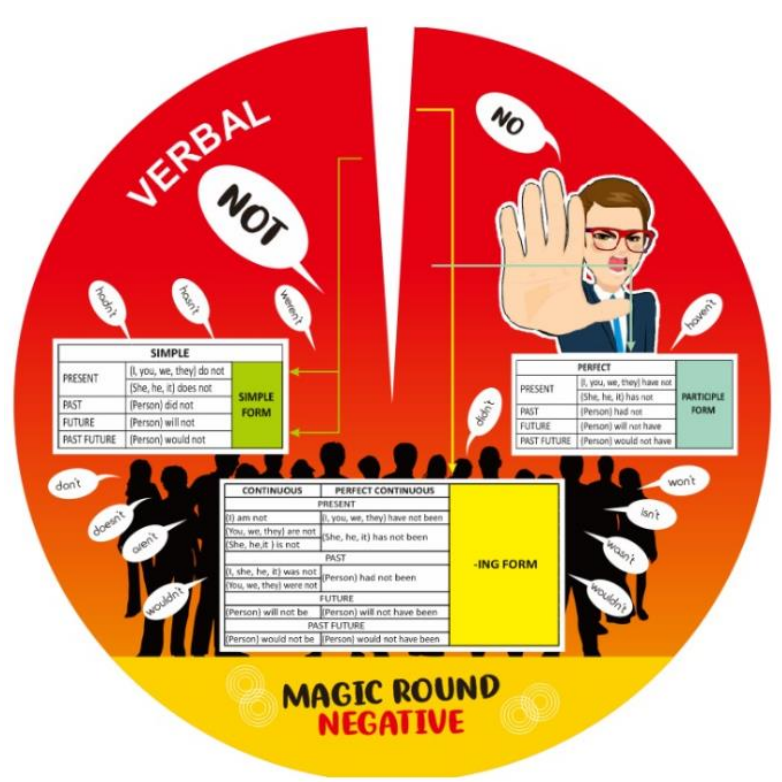

Figure 1. Layer 1 (one)

In the second and third layer, magic round negative was completed by irregular verbs that were put alphabetically and their meanings in Bahasa Indonesia. The amount of verbs themselves were 99 (ninety nine), which were separated into 49 (forty nine) and 50 (fifty). Thus, every time the students/users want to get certain verbs, they only need to spin the media. Of course, the most essential thing is choosing the intended kind of tenses. It will differentiate the pattern of the sentences. Table 5 shows the list of irregular verbs. 
Table 5. Irregular verbs

\begin{tabular}{|c|c|c|c|c|}
\hline No & Simple form & Participle form & -ing form & Meaning \\
\hline 1 & Arise & Arisen & Arising & Muncul \\
\hline 2 & Awake & Awoken & Awaking & Bangun \\
\hline 3 & Bear & Borne & Bearing & Membawa \\
\hline 4 & Become & Become & Becoming & Menjadi \\
\hline 5 & Begin & Begun & Beginning & Memulai \\
\hline 6 & Beseech & Besought & Beseeching & Menegaskan \\
\hline 7 & Bind & Bound & Binding & Mengikat \\
\hline 8 & Bite & Bitten & Biting & Menggigit \\
\hline 9 & Bleed & Bled & Bleeding & Berdarah \\
\hline 10 & Blow & Blown & Blowing & Meniupkan \\
\hline 11 & Break & Broken & Breaking & Merusak \\
\hline 12 & Breed & Bred & Breeding & Ternak \\
\hline 13 & Bring & Brought & Bringing & Membawa \\
\hline 14 & Build & Built & Building & Membangun \\
\hline 15 & Burn & Burnt & Burning & Membakar \\
\hline 16 & Buy & Bought & Buying & Membeli \\
\hline 17 & Catch & Caught & Catching & Menangkap \\
\hline 18 & Choose & Chosen & Choosing & Memilih \\
\hline 19 & Come & Come & Coming & Datang \\
\hline 20 & Creep & Crept & Creeping & Merayap \\
\hline 21 & Cut & Cut & Cutting & Memotong \\
\hline 22 & Deal & Dealt & Dealing & Menyetujui \\
\hline 23 & Dig & Dug & Digging & Menggali \\
\hline 24 & Do & Done & Doing & Melakukan \\
\hline 25 & Draw & Drawn & Drawing & Menggambar \\
\hline 26 & Dream & Dreamt & Dreaming & Memimpikan \\
\hline 27 & Drink & Drunk & Drinking & Minum \\
\hline 28 & Drive & Driven & Driving & Mengendarai \\
\hline 29 & Dwell & Dwelt & Dwelling & Menetap \\
\hline 30 & Eat & Eaten & Eating & Makan \\
\hline 31 & Fall & Fallen & Falling & Jatuh \\
\hline 32 & Feel & Felt & Feeling & Merasa \\
\hline 33 & Fight & Fought & Fighting & Berjuang \\
\hline 34 & Find & Found & Finding & Menemukan \\
\hline 35 & Fly & Flown & Flying & Terbang \\
\hline 36 & Forbid & Forbidden & Forbidding & Melarang \\
\hline 37 & Forecast & Forecast & Forecasting & Memperkirakan \\
\hline 38 & Forget & Forgotten & Forgetting & Melupakan \\
\hline 39 & Forgive & Forgiven & Forgiving & Memaafkan \\
\hline 40 & Forsake & Forsaken & Forsaking & Menyerah \\
\hline 41 & Freeze & Frozen & Freezing & Membeku \\
\hline 42 & Get & Got & Getting & Memperoleh \\
\hline 43 & Give & Given & Giving & Memberikan \\
\hline 44 & Go & Gone & Going & Pergi \\
\hline 45 & Grind & Ground & Grinding & Menggerinda \\
\hline 46 & Grow & Grown & Growing & Tumbuh \\
\hline 47 & Hang & Hung & Hanging & Menggantungkan \\
\hline 48 & Have & $\mathrm{Had}$ & Having & Memiliki \\
\hline 49 & Hear & Heard & Hearing & Mendengarkan \\
\hline 50 & Hide & Hidden & Hiding & Bersembunyi \\
\hline 51 & Hit & Hit & Hitting & Memukul \\
\hline 52 & Hold & Held & Holding & Memegang \\
\hline 53 & Hurt & Hurt & Hurting & Menyakiti \\
\hline 54 & Keep & Kept & Keeping & Menjaga \\
\hline 55 & Kneel & Knelt & Kneeling & Berlutut \\
\hline 56 & Know & Known & Knowing & Mengetahui \\
\hline 57 & Lay & Laid & Laying & Meletakkan \\
\hline 58 & Lead & Led & Leading & Memimpin \\
\hline
\end{tabular}


Tri Agustini Solihati \& Gea Aristi

Magic round: Teaching media for compiling negative sentences

\begin{tabular}{|c|c|c|c|c|}
\hline 59 & Lean & Leant & Leaning & Cenderung \\
\hline 60 & Learn & Learnt & Learning & Mempelajari \\
\hline 61 & Leave & Left & Leaving & Meninggalkan \\
\hline 62 & Lend & Lent & Lending & Meminjamkan \\
\hline 63 & Let & Let & Letting & Membiarkan \\
\hline 64 & Lose & Lost & Losing & Kehilangan \\
\hline 65 & Make & Made & Making & Membuat \\
\hline 66 & Mean & Meant & Meaning & Bermaksud \\
\hline 67 & Meet & Met & Meeting & Bertemu \\
\hline 68 & Seek & Sought & Seeking & Mencari \\
\hline 69 & Sell & Sold & Selling & Menjual \\
\hline 70 & Send & Sent & Sending & Mengirim \\
\hline 71 & Set & Set & Setting & Mengatur \\
\hline 72 & Sew & Sewn & Sewing & Menjahit \\
\hline 73 & Shine & Shone & Shining & Bersinar \\
\hline 74 & Shut & Shut & Shutting & Menutup \\
\hline 75 & Sing & Sung & Singing & Bernyanyi \\
\hline 76 & Sink & Sunk & Sinking & Tenggelam \\
\hline 77 & Sleep & Slept & Sleeping & Tidur \\
\hline 78 & Slide & Slid & Sliding & Meluncur \\
\hline 79 & Smell & Smelt & Smelling & Membau \\
\hline 80 & Speak & Spoken & Speaking & Berbicara \\
\hline 81 & Spell & Spelt & Spelling & Mengeja \\
\hline 82 & Spread & Spread & Spreading & Menyebarkan \\
\hline 83 & Stand & Stood & Standing & Berdiri \\
\hline 84 & Steal & Stolen & Stealing & Mencuri \\
\hline 85 & Swear & Sworn & Swearing & Bersumpah \\
\hline 86 & Sweep & Swept & Sweeping & Menyapu \\
\hline 87 & Swim & Swum & Swimming & Berenang \\
\hline 88 & Take & Taken & Taking & Mengambil \\
\hline 89 & Teach & Taught & Teaching & Mengajar \\
\hline 90 & Tell & Told & Telling & Menceritakan \\
\hline 91 & Think & Thought & Thinking & Berfikir \\
\hline 92 & Throw & Thrown & Throwing & Melempar \\
\hline 93 & Thrust & Thrust & Thrusting & Mendorong \\
\hline 94 & Tread & Trodden & Treading & Menapaki \\
\hline 95 & Undergo & Undergone & Undergoing & Menjalani \\
\hline 96 & Underwrite & Underwritten & Underwriting & Menanggung \\
\hline 97 & Withdraw & Withdrawn & Withdrawing & Menarik \\
\hline 98 & Wring & Wrung & Wringing & Memeras \\
\hline 99 & Write & Written & Writing & Menulis \\
\hline
\end{tabular}
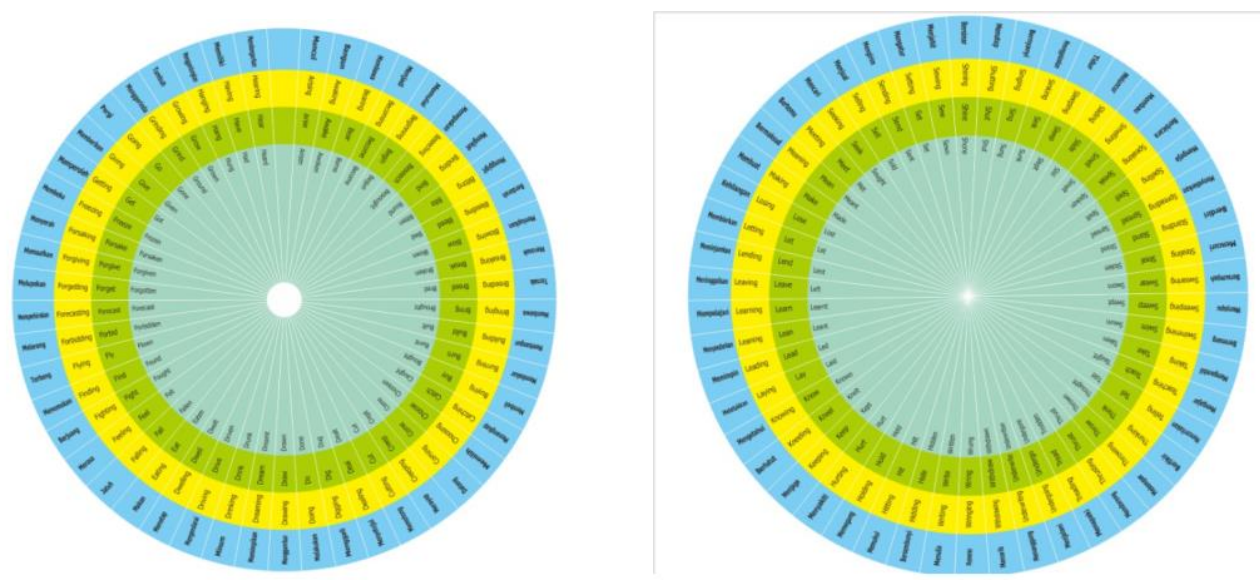

Figure 2. Layer 2 (two) and 3 (three) 
In the fourth layer, magic round negative was completed by tenses explanation and sentence examples. The explanation itself was delivered in Bahasa Indonesia to facilitate the students/users to comprehend the usage of tenses. Different tenses would be used in different situation. In contrast, the sentence examples were written in English in

\section{https://journal.uniku.ac.id/index.php/IEFLJ/index}

the form of simple sentences and it used the same verbs to easily differ the type of tenses. The following magic round was the final product after being examined and validated by both technology and material experts. As it was validated in 3 scale of trial, the result was shown in Table 6 .

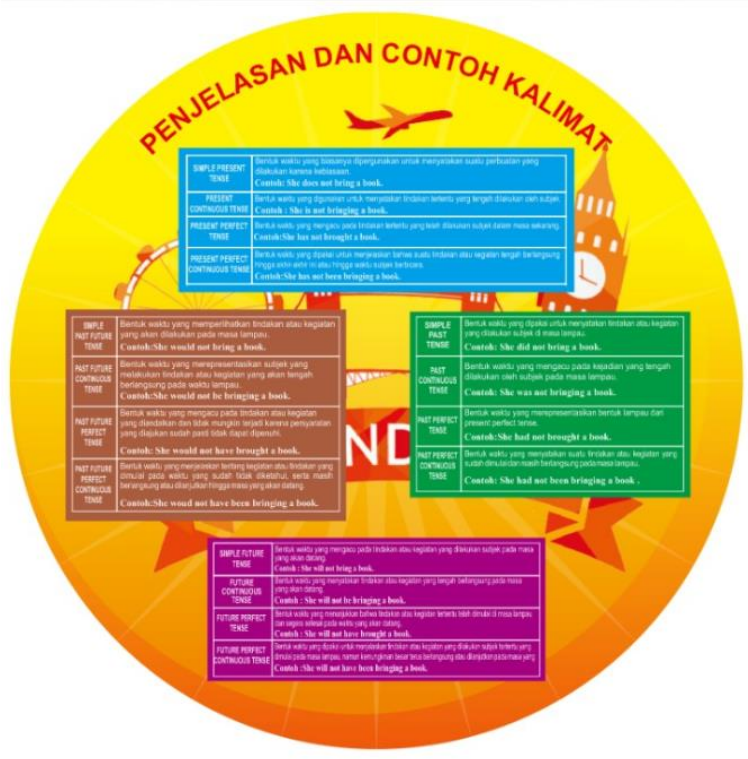

Figure 3. Layer 4 (four)

Table 6. Validation from experts

\begin{tabular}{|c|c|c|c|c|c|}
\hline \multicolumn{3}{|c|}{ Technology Expert } & \multicolumn{3}{|c|}{ Material Expert } \\
\hline $\begin{array}{c}\text { Individual } \\
\text { Scale }\end{array}$ & Small Scale & Limited Scale & $\begin{array}{c}\text { Individual } \\
\text { Scale }\end{array}$ & Small Scale & Limited Scale \\
\hline $\mathbf{7 3 , 3 3}$ & 78,33 & 81,67 & 76,67 & 81,67 & 86,67 \\
\hline \multicolumn{3}{|c|}{$\begin{array}{l}\text { Valid and practical enough, can be used with a } \\
\text { little revision }\end{array}$} & \multicolumn{2}{|c|}{$\begin{array}{l}\text { Valid and practical enough, } \\
\text { can be used with a little } \\
\text { revision }\end{array}$} & $\begin{array}{l}\text { Quiet valid and } \\
\text { practical, can be used } \\
\text { without revision }\end{array}$ \\
\hline
\end{tabular}

The validation consisted of 15 (fifteen) indicators that had been assessed from 1-4. The above scores were calculated and converted to $100 \%$. Little revision suggested by the experts were; 1) background should be modified by using animation in order to make it more interesting, 2) -ing form and simple form position should be changed, 3) convincing that font size was readable, 4) organize the irregular verbs alphabetically, and 5) choose the arrows' colour in contrast to avoid similar colour among verbs form.

The trial in individual scale was followed by 3 (three) students. Each of them had high, medium, and low cognitive level. These assessments were fulfilled by teacher, observer, and students. Students were evaluated both by responding to the questionnaire and doing the test. 


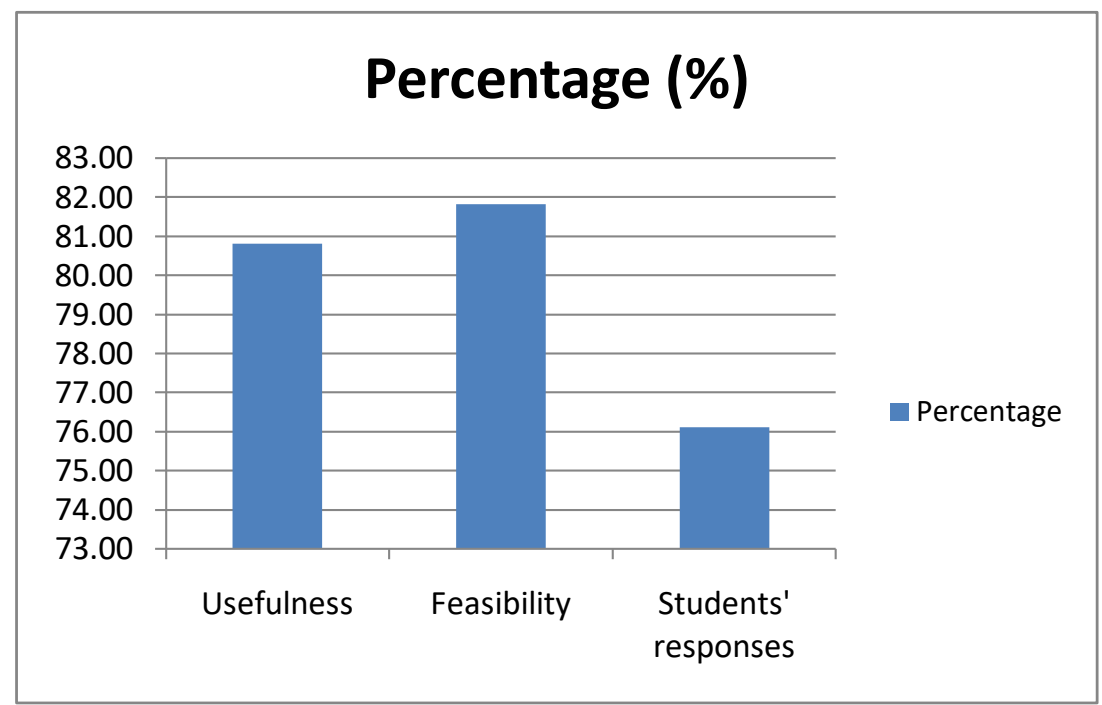

Diagram 1. Usefulness, feasibility test, and students' responses in individual scale

The diagram shows the score of questionnaire which evaluates magic round negative and teacher's guide book. It was done by both teacher and observer. The result was $80.30 \%$ and $81.82 \%$. Meanwhile, students' responses regarding the effectiveness of teaching media reached
76.11\%. Those scores proved that magic round negative was valid and practical, and can be used with little revision. Furthermore, the result of students' learning evaluation had passed the minimum standard score. It was 70.

Table 7. Students' achievement result in individual scale

\begin{tabular}{ccccc}
\hline No. & Name & Pre-Test & Post-Test & Information \\
\hline 1. & R-1 & 65 & 75 & Completed \\
2. & R-2 & 50 & 85 & Completed \\
3. & R-3 & 45 & 70 & Completed \\
\hline
\end{tabular}

The trial in small scale was followed by 6 (six) students with different cognitive level. Those were high, medium, and low grade. After fulfilling the questionnaire for evaluating usefulness, feasibility, and students' responses, here was the result.

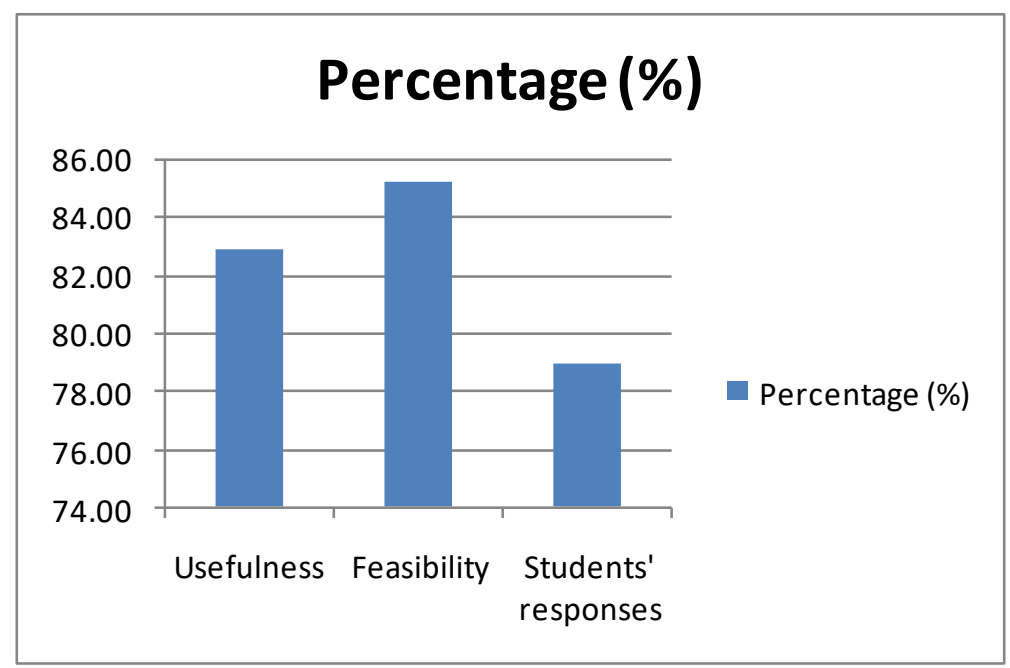

Diagram 2. Usefulness, feasibility test, and students' responses in small scale 
By looking at the score above, it reached $82.85 \%, 85.23 \%$, and $78.89 \%$. Those scores showed that magic round negative was valid and practical enough, and can be used with a
https://journal.uniku.ac.id/index.php/IEFLJ/index

little revision. The result of achievement test passed the minimum standard score of 70 (seventy). It was shown in Table 9.

\begin{tabular}{ccccc}
\multicolumn{5}{c}{ Table 9. Students' achievement result in small scale } \\
\hline No. & Name & Pre-Test & Post-Test & Information \\
\hline 1. & R-1 & 60 & 85 & Completed \\
2. & R-2 & 70 & 85 & Completed \\
3. & R-3 & 45 & 80 & Completed \\
4. & R-4 & 50 & 75 & Completed \\
5. & R-5 & 65 & 80 & Completed \\
6. & R-6 & 60 & 80 & Completed \\
\hline
\end{tabular}

The last product trial was in limited scale. It was followed by 29 (twenty nine) students. It consisted of various cognitive level; high, medium, and low levels.

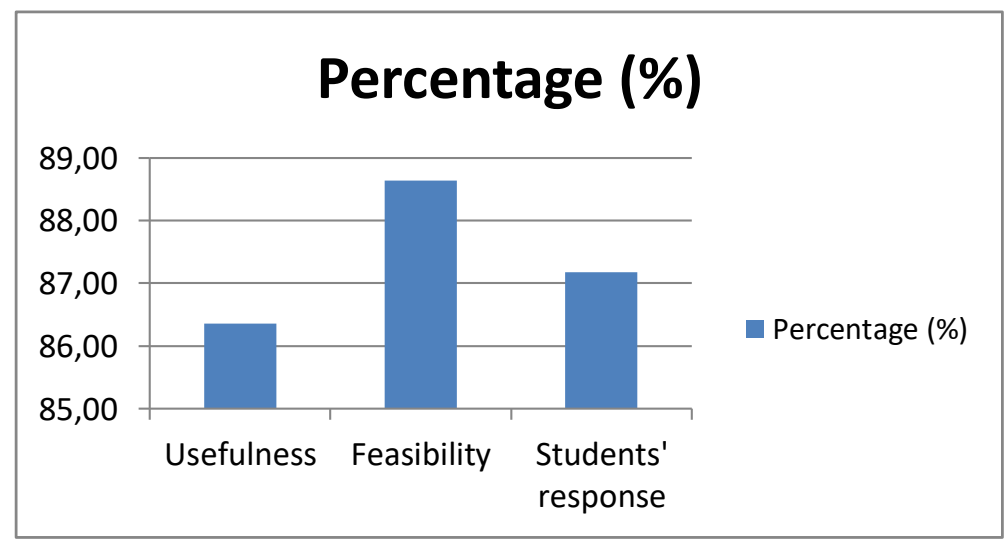

Diagram 3. Usefulness, feasibility test, and students' responses in limited scale

By observing the above diagram, the scores were $86.36 \%, 88.64 \%$, and $87.18 \%$. Those scores implied that magic round negative is a teaching media that is quiet valid and practical, and can be used without revision. Moreover, the achievements test that consists of 35 (thirty five) matching exercise had also passed the minimum standard of 70 (seventy). The students' score in the test is presented in Table 10.

Table 10. Students' achievement result in limited scale

\begin{tabular}{ccccc}
\hline No. & Name & Pre-Test & Post-Test & Information \\
\hline 1. & R-1 & 70 & 90 & Completed \\
2. & R-2 & 50 & 85 & Completed \\
3. & R-3 & 45 & 85 & Completed \\
4. & R-4 & 40 & 85 & Completed \\
5. & R-5 & 45 & 80 & Completed \\
6. & R-6 & 45 & 75 & Completed \\
7. & R-7 & 55 & 90 & Completed \\
8. & R-8 & 60 & 90 & Completed \\
9. & R-9 & 50 & 75 & Completed \\
10. & R-10 & 60 & 95 & Completed \\
11. & R-11 & 45 & 85 & Completed \\
12. & R-12 & 50 & 70 & Completed \\
13. & R-13 & 80 & 95 & Completed \\
14. & R-14 & 75 & 90 & Completed \\
15. & R-15 & 65 & 95 & Completed \\
\hline
\end{tabular}


Tri Agustini Solihati \& Gea Aristi

Magic round: Teaching media for compiling negative sentences

\begin{tabular}{lllll}
\hline 16. & R-16 & 60 & 95 & Completed \\
17. & R-17 & 55 & 90 & Completed \\
18. & R-18 & 55 & 85 & Completed \\
19. & R-19 & 45 & 95 & Completed \\
20. & R-20 & 50 & 85 & Completed \\
21. & R-21 & 45 & 75 & Completed \\
22. & R-22 & 50 & 85 & Completed \\
23. & R-23 & 70 & 95 & Completed \\
24. & R-24 & 55 & 90 & Completed \\
25. & R-25 & 60 & 90 & Completed \\
26. & R-26 & 45 & 85 & Completed \\
27. & R-27 & 45 & 85 & Completed \\
28. & R-28 & 50 & 95 & Completed \\
29. & R-29 & 65 & 80 & Completed \\
\hline
\end{tabular}

From all scale in product trial, students' responses were quiet positive. They were very happy and motivated to learn, the material was more understandable so that the students engaged more in learning, learning activity was very interesting, interactive, and brought the students to be autonomous, the media was very beneficial, the students were able to be cooperative, the students did want the teachers to use the media while teaching, the font size and type were readable, and the media was colourful.

\section{CONCLUSION}

From the analysis, it can be concluded that magic round negative had been successfully developed to assist students in arranging negative sentences. The sentences were applied in 16 (sixteen) types of tenses. Besides, the students were also able to enrich their vocabulary mastery, especially for the irregular verbs because magic round negative is completed by 99 (ninety-nine) irregular verbs with their meaning in Bahasa Indonesia. Furthermore, magic round negative was also suitable to use not only for senior high school students, but also for the beginner. Thus, everyone who is interested in learning English can use magic round negative as learning media since it is able to lead the users to be autonomous learners and the material was completely developed with joyful way to play and practice. To sum up, magic round negative is a quiet valid and practical teaching media, and can be used without revision.

\section{ACKNOWLEDGEMENT}

We would like to express our highest gratitude to MAN 2 Tasikmalaya where this research was carried out, especially for English teacher and students of XI-IIK 1, the technology and material experts, the dean of Faculty of Education and Teacher Training, and all of the lecturers in Universitas Perjuangan Tasikmalaya. Thanks for being supportive and participated to accomplish this research.

\section{REFERENCES}

Daryanto. (2016). Media pembelajaran. Yogyakarta: Gava Media.

Haryudin, A., \& Argawati, N. O. (2018). Lesson study to improve student English grammar mastery using jigsaw technique to the third semester of IKIP Siliwangi. Indonesia EFL Journal, 4(1), 49-56. doi: 10.25134/ieflj.v4i1.798.

Manan, N. A. (2017) Whatsapp mobile tool in second language learning. Indonesia EFL Journal, 3(1), $87-92$

Murphy, R. (1987). English Grammar in use. Great Britain: Cambridge University Press.

Solihati, et al. (2016). The effect of using smart wheel toward the skill of arranging simple sentences (Pengaruh penggunaan smart wheel terhadap keterampilan menyusun kalimat sederhana). Jurnal Saung Guru, IX(3).

Solihati, et al. (2017). Pengembangan magic round pada pembelajaran tenses untuk penyusunan kalimat affirmative (Unpublished paper). Tasikmalaya: Universitas Perjuangan.

Solihati, T. A., \& Aristi, G. (2018). Akselerasi pemahaman tenses dalam menyusun kalimat negative dengan magic round. Jurnal Sosial \& Humaniora IKRA-ITH Humaniora, 2(3), 126132.

Soviyah, S., \& Etikaningsih, D. R. (2018). Instagram use to enhance ability in writing descriptive 
Indonesian EFL Journal (IEFLJ)

Volume 5, Issue 1, January 2019

texts. Indonesian EFL Journal, 4(2), 32-38. doi: 10.25134/ieflj.v4i2.1373.

Sugiyono. (2010). Metode penelitian pendidikan pendekatan kuantitatif, kualitatif, dan $R \& D$. Bandung: Alfabeta.
p-ISSN 2252-7427, e-ISSN 2541-3635

https://journal.uniku.ac.id/index.php/IEFLJ/index

Widoyoko, S. E. P. (2012). Teknik penyusunan instrumen penelitian. Yogyakarta: Pustaka Pelajar. 
Tri Agustini Solihati \& Gea Aristi

Magic round: Teaching media for compiling negative sentences 